\title{
Finding the Causal Relationship between Child Abuse and Teenage Pregnancy: Perspectives of the Crawford University Students in Nigeria
}

\author{
Okunola Ras hidi Akanji ${ }^{1}$, OJO Matthias Olufe mi Dada,"* \\ ${ }^{1}$ Department of Sociology, University of Ibadan, Nigeria \\ ${ }^{2}$ Department of Sociology, Crawford University of the Ap ostolic Faith Mission, Igbesa, Ogun State, Nigeria
}

\begin{abstract}
Poverty has become a general household problem in every home in Nigeria. It has prompted the occurrences of other social problems like crime, insecurity and abuse, especially the abuse of the minor (Children) in the society. The abuse of the children has become a platform for the problem of teenage pregnancy among the female children in Nigeria. With sampled students $(n=180)$ fro $m$ a Nigerian Private University, this paper examined the perspectives of the university students on causal relationship between child abuse and teenage pregnancy. The University of ourcase study was purposively selected, while convenience sampling was used in selecting the students who participated in the study. Frequency distribution and percentage were used as method of data analyses, while chi-square method was used in testing the hypotheses stated in the study. The information and the data gathered fro $m$ the students through the questionnaire, wh ich was our research instrument, reflected that child abuse and teenage pregnancy were overwhelmingly acknowledged as social problems in Nigeria. The hypotheses tested showed a causal re lationship between poverty and teenage pregnancy, child neglect and teenage pregnancy, and child abuse of all forms and teenage pregnancy. The study recommends pro active interventions from the parents, the government, the non-governmental organizations and relig ious bodies in Nigeria, in curb ing the problem of child abuse and teenage pregnancy. The implications of these were discussed in this paper.
\end{abstract}

Keywords Poverty, Child Abuse, Child Neglect, Teenage Pregnancy, Social Problem

\section{Introduction}

The purpose of this research work is to investigate a correlation between child abuse and teenage pregnancy and measures that can be taken to address the problem of child abuse and teenage pregnancy.

Abuse is not a new phenomenon in human history. Most of us had been susceptible to abuse of various forms in the past. Occurrences of child abuse have continued in epidemic proportions. In most cases, abuse happens when children are reared in setting in which their contacts with their parents are either reduced or absent. However, living with one's parent does not guarantee that a child will receive tender loving care. In this direction[34] gave some of the examples of various percentages of children who go through one form of abuse or the other as follows:

54.9 percent parents have slapped their children.

30.7 percent have pushed, grabbed or shoved their children

9.7 percent have hit their children with an object.

* Corresponding author:

fem femty@yahoo.com (OJO Matthias Olufemi Dada)

Published online at http://journal.sapub.org/ijpt

Copyright (C) 2012 Scientific \& Academic Publishing. All Rights Reserved
2.7 percent have thrown something at their children.

1.3 percent have kicked or bitten their children, or hit them with their fists

6.0 percent have beaten up their children.

0.2 percent have threaten their children with knife or gun

0.2 percent actually stabbed or shot their children.

Researchers believe that many cases of child abuse go unreported and that the actual incidences are much higher[14] and[18].

[7] see child abuse as 'an act of omission from parents which interfered with the chance of children in developing to their normal potentials as human beings'. The national council on child abuse and violence states that abuse robs children of the opportunity to develop healthy and trusting relationships with adults and this contributes to low self esteem and impairs healthy psycho-social development which lasts a long time.

[6] were concerned with what can possibly lead to the inhuman treatment of children. According to them, some of the contributing risk factors lie in the characteristics of parents and their children; some are attributed to ecological factors such as the quality of the neighbourhood and available support system. Many others are related to the life experiences and stresses family members encountered. 
[6] observed that abuse is likely to occur when only one risk factor is present. However, in some cases, it is the occurrence and interaction among multiple risk factors, especially in the absence of few protective factors such as: supportive marital relationship, social network and community resources, high intelligence and education, good health and adaptability that is likely to lead to abuse.

Child abuse may expose the child to a lot of dangers physically and an abused child may be exposed to sexual assault like rape. Once this happen, it will affect all other area of the child's life such as unwanted teenage pregnancy for girls or it leads to school dropout. Child becomes dysfunctional in the society as a result of these problems.

Most teenagers do not plan their first sexual experience; rather, it is something that just happens to them based on the influence by female counterparts. Nearly 10 percent of adolescent or teenager girls get pregnant each year. Teenage pregnancy is referred to as an 'under-age girl becoming pregnant'. Studies have found that between 20-30 percent of pregnancies in teenagers are direct results of rape, while $60 \%$ of teenage mothers have unwanted sexual experiences preceding their pregnancies before 15 years when they were coerced by males who were at least six years older than them[3].

Child abuse has become a problematic issue in Nigeria. Millions of Nigerian children face the problem in appalling circumstances. This problem not only affected the survival of the children but creates a formidable obstacle for the development of the children[11] and[13].

The problem of child abuse and teenage pregnancy is a disturbing issue in Nigerian society. If the problem is not critically addressed it may create a lot of damage to the society. The problem will affect both the society and the future lives of the teenagers involved. Hence, there is a need for continuous investigation into the problem of child abuse and teenage pregnancy in Nigeria. Unfortunately, services for investigation and amelioration of the problem are under -resourced.

This research study poses questions that are fundamental to the problem of child abuse and teenage pregnancy as follows:

1. What are the causes of child abuse?

2. Is there a link between poverty and teenage pregnancy?

3. Is there a relationship between child neglect and teenage pregnancy?

4. Is there a significant correlation between child abuse and teenage pregnancy?

As a result of the above research questions, our study attempted to:

1. Examine the causes of child abuse

2. Investigate a link between poverty and teenage pregnancy.

3. Identify a relationship between child neglect and teenage pregnancy

4. Investigate causal relationship between child abuse and teenage pregnancy.

The study focuses on child abuse and teenage pregnancy.
The scope of our study covered only Crawford University, Igbesa, Ogun State Nigeria. The students were sampled as research respondents and the information supplied by them formed the bases for the data used in this research study.

The constraints which limited our study were: fund, time and resource personnel to assist in the survey study. It was a self sponsored survey research work.

\section{Literature Review, Methodology Applied and Discussion of the Findings}

\subsection{Concept of Child Abuse}

The concept of child abuse has no specific definition as it varies from individuals, ethnic, religious and professional bodies. The practice of child abuse has manifested in all socio-economic classes, religion, ethnic and cultural groups. Child abuse is not a new social problem in history. There is a considerable evidence to show that prior to the European industrial revolution and certainly during the period, there had been systematic abuse of child ren for both economic an ideological reasons. Since then attempts have been made to seek an explanation to the problem and important ways of systematically controlling and preventing it as well as treating the victimized child. Despite the attempt and the considerable attention, the problem still remains in recent years, a largely neglected policy area, one in which it has not been possible to obtain any widespread understanding or agreement as to the steps that can be taken to combat It[4].

According to[4], child abuse is generally defined as 'any act of commission or in the case of neglect, omission that endangers or impairs a child's physical, developmental and emotional wellbeing'. Child abuse encompasses physical, psychological and sexual abuse and neglect.

[30] stated that children who are physically abused are more likely to face variety of emotional problems and children who are sexually abused exposed their genitals to their parents, friends and strangers who engage in sexual acts with them or for pornographic purposes.[23] and[22] reported that child is vulnerable to extreme maltreatment such as child scolding, prostitution and labour. Female children who are between the ages of seven and thirteen years experience sexual abuse than male children. So me of these children live with their parents, step parents, single mothers with cohabiting male, abusive parents and substance abusive family member, who, out of aggression, abuse their own children[38].[20] observed that child abusers are likely to have experienced abuse themselves. Abusive behavior is transmitted across generation with studies showing that some $30 \%$ of abused children became abusive parents. Children who experience abuse and violence may adopt the behaviour as a model for their own parenting, and parents who cannot differentiate between discipline and abuse also abuse their o wn children[17]. The potential for maltreat ment exists in all social strata and every family at some points in a child's development. There is no single explanation for child 
abuse. Child abuse results from a complex combination of personal, social and cultural factors. It can be caused by inter-generational transmission of violence, social isolation, low commun ity involvement and types of families[15].

\subsection{Types of Child Abuse}

Child abuse can be categorized into the followings:

1. Physical abuse

2. Physical neglect

3. Verbal abuse

4. Emotional/Psychological abuse

5. Street children

6. Child labour

7. Child abandonment

8. Sexual abuse

The categories listed above are explained below:

\subsubsection{Physical Abuse}

Physical abuse involves physically harmful actions directed against a child. It involves any inflicted inju ries such as bruises, burns, injuries, fractures, poisoning, striking, kicking or any other actions that result into a physical impairment of the child[33]. Physical abuse of children can be intentional or unintentional. It can also be an act of omission or commission on the part of parents, elders or caretakers[8]. Physical abuse could lead to severe injuries, bruises, burns, incapacitation, disability or even death. This physical violence may come as a result of lack of physical affection from parents in childhood[29].

\subsubsection{Physical Neglect}

Physical neglect can be defined as neglect of the physical appearance, nutritional, med ical and safety needs of the child. It manifests in unkempt appearance, inappropriate dressing, anger, unbalance diet and non-immunization of children and ante-natal neglect which are aspects of the neglect[27] . Child neglect, most times, is unintentional (human reasoning demands that children should be taken care of), however, certain socio economic and cultural constraints may lead to the neglect[11] .

\subsubsection{Verbal Abuses}

This is another form of abuse which is often taken for granted by parents and guardians. Verbal abuse of children has been observed as having negative effects on psychological and emotional development of the child. It is the most commonly used form of abuse. Verbal expressions make a child feel bad (about him or she) and this usually affects the esteem of the child[29] .

\subsubsection{Emotional Abuse /Psychological Abuse}

Emotional/Psychological abuse usually starts with physical abuse and emotional neglect. Emotional neglect is a psychological internal perception[2].

The effect of emotional abuse can be crippling. They are usually diagnosed by psychiatrists and psychologists.
Emotional abuse is an injury to a child's emotional psychological self which is meant to be punitive. It is experienced as a form of parental hostility in terms of terrorizing, rejections and insults. It manifests in forms of aggression, retreatism and general feelings of incompetence. Emotional neglect also comes in forms of emotional deprivation, lack of cares, love and empathic attention towards a child[29].

\subsubsection{Street Hawking}

Street hawking by child ren is another form of abuse. Street hawking encourages sexual abuse. This may occur in three levels: exposure to overt genital seduction, exposure to genital stimulation and witnessing adults in the act of sex.Man may lure young female hawkers by buying up all their wares and giving them money. These girls may be shown pornographic pictures in magazines or pornographic video films or the sexual organs of the would be assailants[12].

\subsubsection{Child Abandonment}

This is another form of child abuse. Child abandonment is the most frequently reported form of child abuse and neglect. Most children involved are usually new born babies and those between the ages of 1-3 years. Children can be abandoned in gutters, pit latrines, on rubbish dumps in the bush or along pathways near places like police stations, hospitals e.t.c where they can be easily seen and cared for.

\subsubsection{Child Labour}

Child labour is a prominent way of abusing children. In the poorer parts of the world, like Asia, South America and Africa, acute and wide -spread poverty can be seen as the ma in cause. If child ren do not work, their own survival is at stake[21]. In the African traditional Society, children were source of labour for farming. However, with emergence of industrialization and urbanization, such practice becomes dysfunctional and contemporary; such practice is referred to as child labour[11].

Child trafficking is particularly pernicious type of child labour. It is a practice through which young people below 18 years are handed over by either or both parents or by a guardian to a third person, whether for free or with the intention of exploiting the person or the work of the young person.

\subsubsection{Child SexualAbuses}

Sexual abuse is defined as 'involving any minor child in the sexual gratification of an adult'. Sexual abuse includes: oral to genital, genital to genital, rectal contacts and showing pornography to child or using a child in the production of pornographic films[5]. Sexual abuse most is commonly practiced by an individual known by the victim, parents or other family member. Rarely is the abuser a stranger. Intra familial and incest sexual abuse is difficult to document and 
manage because the child in an additional abuse is coerced not to tell or reveal the abuse while attempts are made to preserve the family unit[5].

[28], in discussing sexual abuse in Africa, argues that one has to be careful to take cultural peculiarities of the practices into cognizance. For example, so me child ren get married as early as five years, though; sexual intercourse may not co me up until she is around ten or twelve years of age, especially in the Northern part of Nigeria where there are several cases of forced marriages and giving out of female child as a gift for marriage.

\subsection{Effects of Child Abuse}

Child abuse has a lot of negative impacts on the victims, and the society at large. The prevailing cases of child abuse, according to research studies, indicate that every day, a significant number of children are exposed to serious abuse and neglect leading to physical and psychological injury and serious long term consequences[19]. When people are abused it can affect every aspect of their lives, especially self-esteem. Teens that are abused often have trouble with sleeping, eating and concentrating. They may not do well at school because they are angry or frightened. They also have a form or kind of distrust for others. They may feel a lot of anger toward other people and themselves and find it difficult to make friends[2].

\subsection{Teenage Pregnancies}

In the past decades, sexual activity has increased among adolescents and also the number of unplanned teen pregnancies. Pregnant teens have been found to be significantly more maladjusted than the adult women. Disassociation and depression are immediate effects of child abuse. Disassociation was found to be associated with reports of becoming pregnant or having abortion in high schools and child abuse history was significantly correlated with make report of girl friends becoming pregnant and reports of girlfriends having abortion in high school[3].

Teenage Pregnancy is defined as 'a teenager or under-aged usually within ages of thirteen to nineteen years becoming pregnant'. The term in every day speech usually refers to women who have not reached legal adulthood, which varies across the world, who become pregnant[3].

\subsection{Causes of Teanage Pregnacy}

Teenage pregnancy can be caused by several factors, some of which are explained below:

\subsubsection{SexualAbuse}

Studies have found that between eleven and twenty percent of pregnancies in teenagers were as a result of rape, while about sixty percent of teenage mothers had unwanted sexual experiences (abuse) preceding their pregnancy. One in five teenage fathers admitted to forcing girls to have sex with them. Multiple studies have indicated a strong link between early childhood sexual abuse and subsequent teenage pregnancy in industrialized countries [31].

Up to seventy percent of women who gave birth in their teens were molested as young girls. In some countries, sexual intercourse between a minor and an adult is not considered consensual. In those countries, sex with a minor is therefore considered as statutory rape[36].

\subsubsection{Dating Violence}

Studies have indicated that adolescent girls are often in abusive relationships. They have also reported that knowledge of their pregnancy often intensified violent and controlling behaviour on the part of their boyfriends. Many teenage mothers had been beaten by their boyfriends. $51 \%$ had experienced attempts of birth control sabotage and $21 \%$ experienced schools or work sabotage[24]. Studies have also found that girls whose fathers left the family early in their lives had the highest rate of early sexual activity and adolescent pregnancy[37].

\subsubsection{Childhood Environments}

Research has shown that women exposed to abuse, domestic violence and family strife in childhood are more likely to become pregnant as teenagers and the risk of becoming pregnant as a teenager increases with the number of adverse childhood experience. Studies have also found that boys raised in homes with a battered mother or who experienced physical violence directly, are significantly more likely to impregnate a girl[26].

\subsubsection{Low Educational Expectations}

Low educational expectations have been identified as a risk factor of teenage pregnancy. A girl who is not so educated and has a mother that is illiterate is also more likely to become pregnant as a teenager if the mother also gave birth in her teen.

Adolescent pregnancy can also be caused by a breakdown of commun ication between parents and child, and as a result of inadequate parental supervision.

\subsubsection{Foster Care}

Foster care youths are more likely, than their peers, to become pregnant as teenagers. Studies found that the birth rate of girls in foster care was more double the rate of their peers outside the foster care system[9].

\subsection{Effects of Teenage Pregnancy}

The medical, social and economic cost of unplanned teenage pregnancies can be devastating to mothers and their children. Teen mothers are more likely to have medical complications during pregnancy and prolonged labour. Their babies are more likely to be born prematurely and to have low birth weights. These are caused by inadequate pre-natal care and poor nutrition often experienced by teenage mothers living in conditions of poverty[10]. 
Teenage parenthood creates a number of economic and social disadvantages for young mothers. They are less likely to graduate from high school or attend college. The lack of educational achievement makes it more difficult for them to obtain adequate employment.

They have a lower standard of living and are more likely to require public assistance. Their marriages are more likely to be unstable and they often have more children than they intended[16].

Children born to teen mothers also are at disadvantage. They show lower levels off cognitive functioning and more behavioural and emotional problems, while boys appear to be more affected than girls. The children of teenage mothers do poorly in school and are likely to become pregnant themselves. Teen mothers may also have less knowledge about child rearing than older mothers and may provide their babies with fewer opportunities for stimulation.

\subsection{Research Design}

It was not possible to study every unit of the population under our study. We, therefore, emp loyed the survey design which involves the collection of information from a sample of individuals through their responses to question[36]. It is a popular research design because of its versatility.

\subsubsection{Scope of the Study}

The scope of our study only covered Crawford University of the Apostolic Faith Mission, Igbesa. Ogun State Nigeria. The university was founded in 2005 and is privately own by the Apostolic Faith Mission in Nigeria. The University was established not only to increase the access of youths to University education but also to be able to curb the decay and deformity in the educational system through appropriate moral and spiritual training.

\subsubsection{Study Population}

The study population was made up of the students of the university Crawford University, Igbesa, Ogun State, Nigeria. The University is currently running two colleges with a total of fifteen academic programs. All the students of this university (over 1, 000 of them) were our study population. However, only few were sampled among them.

\subsubsection{Sampling Method and Sampling Size}

We used multi-stage sampling in this study. The site of our study was purposely sampled being a high moral and spiritual private university which encourages moral and spiritual standards of the students against all social vices. It was selected based on our judgment that the university will facilitate our investigation. It was a unique case that was especially informative[1].

Furthermore, convenience sampling was used in selecting the students that participated in the study from each academic programme. The students were the ones that were readily accessible to us. The method was very cheap and quick, considering the fund and time factors which limit this study[1] and[25].

Two hundred students were conveniently sampled from the entire students' population of the two colleges. However, only one hundred and eighty students (180) returned the questionnaire by the time our data were being sorted and analysed.

\subsubsection{Research Instrument}

Questionnaire was the only research instrument used to gather information from our respondents. The questionnaire contained both closed ended questions and open ended questions. The close ended questions were meant to obtain information on specific issues. The open ended questions, on the other hand, allowed the respondents to express thems elves.

The procedure for the distribution of the questionnaires was through hand delivery. The questionnaires were given to them through personal contacts and were collected back through the same procedure. This was done to yield high rate of returns. However, only 180 questionnaires were returned out of 200 questionnaires given out.

\subsubsection{Data Analysis}

Our data were analysed through the adoption of frequency percentage and inferential statistics (chi-square).

For the frequency percentage the formula below was used: $\mathrm{x} / \mathrm{p}=100 / 1$

Where $\mathrm{x}$ is the number of the responses and $\mathrm{P}$ is the total population.

For the Chi-Square:

$$
\begin{aligned}
& \mathrm{X} 2=\mathrm{E}(\mathrm{o}-\mathrm{e}) 2 \\
& \mathrm{e} \\
& \mathrm{o}=\text { the observed frequency } \\
& \mathrm{e}=\text { expected frequency } \\
& \mathrm{E}=\frac{\text { row total }- \text { column total }}{\text { grand total }}
\end{aligned}
$$

Grand total $=$ total nu mber of the respondents used in this study.

The significance level to be used is $95 \%(0.05)$ and the degree of freedom $(\mathrm{df})$

$$
=(\mathrm{r}-1)(\mathrm{c}-1)
$$

$r=$ the number of rows

$\mathrm{c}=$ the number of colu mn

\subsubsection{Research Hypotheses}

We tested hypotheses in this research work. We tried to make some tentative statements about the empirical reality, involving a relationship between two variables [35].

Three of such tentative statements were made as follows:

1. There is a significant relationship between poverty and teenage pregnancy.

2. There is a significant relationship between child neglect and teenage pregnancy 
3. There is a significant relationship between child abuse and teenage pregnancy.

As stated earlier on, chi-square was used in testing the above stated hypotheses.

\subsubsection{Limitation of the Study}

This research work was self -sponsored. Fund was a constraint in carrying out the research. The research work was equally limited by time and personnel resources (res earch as sistants). Hence, we limited our study to only one private university and employed the sampling method that was not costly in time and fund i.e. convenience sampling.

\subsubsection{Eth ical Is sues}

We took the cognizance of ethics in research into consideration in this study. We informed our respondents on what the research was all about and the purpose of it. We sought their consents before this work was carried out. We ensured that the anonymity of every respondent was followed. The information and data supplied were analysed in an aggregate form without any link to any respondent. The information and the data were kept confidential and only used for the purpose of this study.

\subsection{Data Presentation, Analysis and Discussion of the Findings}

This section treated the aspects of data presentation, analysis and discussion of the findings we discovered in the field survey we conducted on the topic. It examined the characteristics of the respondents and their responses to the issues related to abuse and teenage pregnancy.

Table 1. Table showing some characterist ics of the respondents

\begin{tabular}{|c|c|c|c|}
\hline & & Frequency & Percentage \\
\hline 1 & Gender & & \\
& Male & 82 & 45.6 \\
& Female & 98 & 54.4 \\
& Total & 180 & 100.0 \\
\hline \multirow{4}{*}{2} & Age & & \\
& $15-20$ & 104 & 57.8 \\
& $21-25$ & 68 & 37.8 \\
& 26 and above & 8 & 4.4 \\
\hline 3 & Total & 180 & 100.0 \\
& Levels of Study & & \\
& 100 & 37 & 20.6 \\
& 200 & 52 & 28.9 \\
& 300 & 47 & 24.1 \\
& 400 & 44 & 100.0 \\
& Total & 180 & \\
& & & 65.6 \\
\hline \multirow{4}{*}{4} & College & & 34.4 \\
& Business and & 118 & 100.0 \\
& social sciences & & \\
& Natural and & & \\
& Applied & & \\
& Sciences & 180 & \\
& Total & & \\
\hline
\end{tabular}

Source: Researchers' Survey, 2012
A critical look at the above table shows that 82 respondents $(45.6 \%)$ were male, while 98 respondents $(54.4 \%)$ were female. Both sexes were fairly represented in our study. The issue of abuse of child and teenage pregnancy concerned both boys and girls. However, girls were more concerned than the boys because teenage pregnancy is primarily the is sue concerning the girls in the society.

Another important variable which was relevant to this study is age. We examined the age distribution of our respondents. In our analyses, 104 respondents $(57.8 \%)$ were within the range of 15 years to 20 years. 68 respondents $(37.8 \%)$ were within 21 years and 25 years while 8 respondents $(4.4 \%)$ were 26 years and above.

Our data show that majority of our respondents were teenagers who were the main focus of our research work.

We equally examined the levels of study of our respondents. 37 respondents $(20.6 \%)$ were in the first year of their studies. 52 respondents $(28.9 \%)$ were in the second year. 47 respondents $(26.1 \%)$ were in third year and 44 respondents $(24.4 \%)$ were in the fourth year. All the levels as we observed, were fairly represented in our study.

At present, there are two colleges in the university of our study. 118 respondents $(65.6 \%)$ were in the college of Business and Social Sciences, while 62 respondents $(34.4 \%)$ were in the college of Natural and Applied sciences.

College of Business and Social Sciences consist of Accounting, Banking and Finance, Business Administration, Marketing, Economics, Political Science and International Relation, Industrial Re lation and Personnel Management and Sociology. College of Natural and Applied Sciences consists of Mathematics, Computer and Information Technology, Biological Sciences, Bio-Chemistry, Industrial Chemistry, Physics with Electronics, and Geology.

Table 2. Table showing the information on respondents' family and parents

\begin{tabular}{|c|c|c|c|}
\hline & Variable & Frequency & Percentage \\
\hline \multirow{4}{*}{1} & Family Type & & \\
& Monogamy & 153 & 85.0 \\
& Polygamy & 27 & 15.0 \\
& Total & 180 & 100.0 \\
\hline \multirow{4}{*}{2} & Numbers of Siblings & & \\
& $1-5$ & 100 & 55.6 \\
& $6-10$ & 76 & 42.2 \\
& $11-15$ & 4 & 2.2 \\
& Total & 180 & 100.0 \\
\hline \multirow{4}{*}{3} & Type of Parenthood & & \\
& Single parent & 37 & 20.6 \\
& Two parents & 143 & 79.4 \\
& Total & 180 & 100.0 \\
\hline \multirow{4}{*}{4} & Parent Education & & \\
& Educated & 173 & 96.1 \\
& Uneducated & 7 & 3.9 \\
& Total & 180 & 100.0 \\
\hline
\end{tabular}

Source: Researchers' Survey, 2012

We examined Variables that have to do with the family and the parents of our respondents in our study. The above table shows the outcomes of the data obtained regarded those variables. 
The first variable is the family type of our respondents. $153(85.0 \%)$ came from monogamous family while 27 $(15.0 \%)$ came from polygamous family. Although, the cultures in Nigeria favour polygamy, yet, as a result of influences of western culture on Nigerian society, the Nigerians are now fond of embracing monoga my which is a foreign family system to Nigerians. Hence, monogamy is gradually dominating the Nigerian society.

We requested our respondents to signify the number of the siblings in their families. When the data were sorted out, 100 respondents $(55.6 \%)$ have between 1 to 5 siblings in their families. 76 respondents $(42.2 \%)$ have between 6 and 10 siblings, while 4 respondents $(2.2 \%)$ have between 11 and 15 siblings.

Table 3. Table, showing the responses of our respondents to some questions on child abuse, teenage pregnancy and other related issues

\begin{tabular}{|c|c|c|c|}
\hline & $\begin{array}{l}\text { QUEST IONS AND } \\
\text { RESPONSES }\end{array}$ & FREQUENCY & PERCENTAGE \\
\hline 1 & $\begin{array}{c}\text { Is child abuse a social } \\
\text { problem? } \\
\text { Yes } \\
\text { No } \\
\text { I don't know } \\
\text { Total } \\
\end{array}$ & $\begin{array}{c}149 \\
16 \\
10 \\
180\end{array}$ & $\begin{array}{c}82.8 \\
10.6 \\
5.6 \\
100\end{array}$ \\
\hline 2 & $\begin{array}{c}\text { Is teenage pregnancy a } \\
\text { social problem? } \\
\text { Yes } \\
\text { No } \\
\text { I can't say } \\
\text { Total }\end{array}$ & $\begin{array}{c}138 \\
25 \\
17 \\
180\end{array}$ & $\begin{array}{c}76.7 \\
13.9 \\
9.4 \\
100.0\end{array}$ \\
\hline 3 & $\begin{array}{c}\text { Can child abuse cause } \\
\text { teenage pregnancy? } \\
\text { Yes } \\
\text { No } \\
\text { I can't say } \\
\text { Total } \\
\end{array}$ & $\begin{array}{c}165 \\
25 \\
17 \\
180\end{array}$ & $\begin{array}{c}91.7 \\
13.9 \\
9.4 \\
100.0\end{array}$ \\
\hline 4 & $\begin{array}{c}\text { Is there a relationship } \\
\text { bet ween sexual abuse } \\
\text { and teenage pregnancy? } \\
\text { Yes } \\
\text { No } \\
\text { I don't know } \\
\text { Total }\end{array}$ & $\begin{array}{c}160 \\
12 \\
8 \\
180\end{array}$ & $\begin{array}{c}88.9 \\
6.7 \\
4.4 \\
100.0\end{array}$ \\
\hline 5 & $\begin{array}{c}\text { Does teenage pregnancy } \\
\text { affects female teenagers } \\
\text { involved? } \\
\text { Yes } \\
\text { NO } \\
\text { Total } \\
\end{array}$ & $\begin{array}{c}151 \\
29 \\
180 \\
\end{array}$ & $\begin{array}{c}83.9 \\
16.1 \\
100.0 \\
\end{array}$ \\
\hline 6 & $\begin{array}{c}\text { Does teenage pregnancy } \\
\text { have effects on Nigerian } \\
\text { society? } \\
\text { Yes } \\
\text { No } \\
\text { I don't know } \\
\text { Total } \\
\end{array}$ & $\begin{array}{c}129 \\
14 \\
37 \\
180\end{array}$ & $\begin{array}{c}71.7 \\
7.8 \\
20.5 \\
100.0\end{array}$ \\
\hline
\end{tabular}

Source: Researchers' Survey, 2012

We also requested our respondents to tell us their parenthood (whether single or both parents) 137 (20.6\%) of our respondents came from a single parent, while the rest, $143(70.4 \%)$ were from both parents. We also requested our respondents to inform us about the educational statuses of their parents. 173 respondents $(96.1 \%)$ said their parents were educated, while 7 (3.9\%) respondents said their parents were not educated.

We asked our respondents to confirm if child abuse is seen as a social problem in the Nigerian society. 149 respondents $(82.8 \%)$ confirmed it as social problem affecting the Nigerian Society. 16 respondents $(10.6 \%)$ denied it being a serious social problem. 10 respondents $(5.6 \%$ cannot say whether it is a social problem or not. However, the high percentage of our respondents, who confirmed child abuse as a social problem, clearly indicated that the awareness of child abuse as a social problem among the students was very high. They were conscious of it as a problem within the Nigerian society.

Teenage pregnancy as a social problem was equally requested to be confirmed by the respondents. 138 respondents $(76.7 \%)$ confirmed that teenage pregnancy is a social problem in Nigeria. 25 respondents $(13.9 \%)$ did not see it as a critical social problem, while 17 respondents $(9.4 \%)$ said they cannot say whether it is a social problem or not. A very high percentage who confirmed it a social problem also signified that teenage pregnancy as a social problem was highly acknowledged.

We requested our respondents to show if there is a causal relationship between child abuse and teenage pregnancy. I65 respondents $(91.7 \%)$ attested that really, there was a causal relationship between child abuse and teenage pregnancy. They were of the opinion that teenage pregnancy can be a resultant effect of child abuse. 25 respondents (13.9\%) denied that there was a causal relationship between the two, while 17 respondents $(9.4 \%)$ cannot say whether there was a causal relationship between the two or not. However, the overwhelming percentage who testified of the causal relationship between child abuse and teenage pregnancy signified the awareness that there was a causal relationship between the two.

Is there a relationship between sexual abuse and teenage pregnancy? We requested our respondents to say their opinions on this. 160 respondents $(88.9 \%)$ confirmed that there was a relationship between sexual abuse and teenage pregnancy. 12 respondents $(6.7 \%)$ were of the opinion that there was no causal relationship whatsoever. 8 respondents (4.4\%) said they did not know whether a casual relationship exists between the two or not. However, available literature shows that a casual relationship exists between sexual abuse and teenage pregnancy, which of course was confirmed by the majority of our respondents.

The effects of teenage pregnancy on the female teenagers involved exist. $151(83.9 \%)$ of our respondents confirmed that female teenager who were involved in teenage pregnancy would feel the effects. Such effects included: Low self esteem and self confidence, social stigma, emotional problem and effects on education of such female teenagers. 29 respondents $(16.1 \%)$ did not see any effects on such female teenagers. 
The society does equally feel the effects of teenage pregnancy. 129 respondents $(71.7 \%)$ confirmed that society does feel the effects too. According to them, whatever things that affect individuals would have the effect on the society in the long run. 14 respondents $(7.8 \%)$ were of the opinion that teenage pregnancy have no effects on the society, while 37 respondents $(20.5 \%)$ did not know whether there were effects of teenage pregnancy on the society or not.

\subsubsection{Hypotheses Testing}

Three hypotheses were tested as stated earlier on:

HYPOTHESSIS 1

H0: There is no significant relationship between poverty and teenage pregnancy

$\mathrm{H} 1$ : There is significant relationship between poverty and teenage pregnancy.

Table 4. Table, showing cross tabulation between teenage prenancy and poverty

\begin{tabular}{|c|c|c|c|c|c|}
\hline $\begin{array}{c}\text { Poverty } \\
\text { related } \\
\text { with } \\
\text { Teenage } \\
\text { Pregnancy }\end{array}$ & \multicolumn{5}{|c|}{ Poverty causes teenage pregnancy } \\
\hline & Agreed & $\begin{array}{c}\text { Strongly } \\
\text { Disagreed }\end{array}$ & Disagreed & $\begin{array}{c}\text { Strongly } \\
\text { Disagreed }\end{array}$ & Total \\
\hline Yes & 69 & 60 & 9 & 0 & 138 \\
\hline No & 16 & 6 & 2 & 1 & 25 \\
\hline $\begin{array}{c}\text { I don't } \\
\text { know }\end{array}$ & 8 & 7 & 1 & 1 & 17 \\
\hline Total & 93 & 73 & 12 & 2 & 180 \\
\hline
\end{tabular}

Source: Researchers' Survey, 2012 $\mathrm{df}=6$

Level of the test of significant 0.05

Tabulated Chi-square $=12.592$

The calculated chi-square $=24.76$

Sample size $(\mathrm{n})=180$

The calculated chi-square is greater than the tabulated chi-square which indicates that the alternative hypothes is will be accepted. Therefore, there is a significant re lationship between poverty which is a cause of child abuse and consequently, teenage pregnancy. Studies have shown that the prevailing cases of child abuse in the society can be traced to poverty. Many households and families are living below average standard of living in many nations of the world. The need of the family to make additional income for their sustenance has pushed them into engaging their children in hawking, prostitution and all forms of abuse. Female children as a result of this problem of poverty may end up becoming pregnant at their teens.

Hypothesis 2

Ho: There is no significant relationship between child neglect and teenage pregnancy.

Hi: There is significant re lationship between child neglect and teenage pregnancy.

From the above, the chi-square calculated is greater than the tabulated chi-square; this indicates that the alternative hypothesis (H1) is accepted. Hence there is a significant relationship between child neglect and teenage pregnancy.
Table 5. Table, showing the cross tabulation between child neglect and teenage pregnancy

\begin{tabular}{|c|c|c|c|c|}
\hline & \multicolumn{4}{|c|}{ Parents' negligence may cause teenage } \\
pregnancy
\end{tabular}

Source: Researchers’ survey, 2012 $\mathrm{df}=4$

Tabulated Chi-square $\left(\mathrm{x}^{2}\right)=9.4 .49$

Calculated Chi-square $\left(\mathrm{x}^{2}\right)=14.427$

Size $(n)=180$

According to[11], child neglect most times was unintentional, due to the fact that ordinary human reasoning demands that children should be taken care of. However, because of certain socio-economic and cultural constraints, neglect comes in. Neglect can be very insidious form of maltreatment and this exposes the children to the forms of abuse like rape and sexual abuse which may eventually lead to teenage pregnancy.

Hypothes is 3

Ho: There is no significant relationship between child abuse and teenage pregnancy

Hi: There is significant relationship between child abuse and teenage pregnancy.

Table 6. Table, showing the cross tabulation between child abuse and teenage pregnancy

\begin{tabular}{|c|c|c|c|c|}
\hline $\begin{array}{c}\text { Child abuse may cause } \\
\text { teenage pregnancy }\end{array}$ & \multicolumn{4}{|c|}{$\begin{array}{c}\text { There is a correlat ion between child abuse } \\
\text { and teenage pregnancy }\end{array}$} \\
\hline & Yes & No & $\begin{array}{c}\text { I don't } \\
\text { know }\end{array}$ & Total \\
\hline Yes & 131 & 20 & 14 & 165 \\
No & 3 & 4 & 0 & 7 \\
I can't say & 4 & 1 & 3 & 8 \\
Total & 138 & 25 & 17 & 180 \\
\hline
\end{tabular}

Source: Researcher

$\mathrm{df}=4$

Calculated Chi-square $\left(\mathrm{X}^{2}\right)=19.247$

Tabulated Chi-square $\left(\mathrm{X}^{2}\right)=9.49$

Sample Size $(n)=180$

The alternative hypothesis will be accepted because the chi-square calculated is higher than the chi-square tabulated. Hence, there is a significant re lationship between child abuse and teenage pregnancy. Studies have shown that some percentages of pregnancies in teenagers were a direct result of rape. Many teenage mothers had unwanted sexual experiences (abuse) preceding their pregnancies and most first intercourse were non-voluntary. Many of them were coerced by males who were far older than them.

\section{Summary, Conclusions and Recommendations}

\subsection{Summary of the Findings}

Most of our respondents (82.8\%) agreed that child abuse is 
a critical social problem in Nigeria like other nations of world. The problem of child abuse cannot be denied. There were frequent reports on the abuse of children across the nations especially in the dailies. We discovered that our respondents $(76.7 \%)$ also admitted teenage pregnancy as a major social problem in Nigeria. Teenage pregnancy is a frequent occurrence across all the geo-political zones in the country. The incidences of teenage pregnancy are very common especially in the Northern part of Nigeria where religion and culture supported early marriage. Many teenagers' health statuses have been seriously affected and impaired by teenage pregnancy.

The majority of the respondents $(91.7 \%)$ were of the opinion that child abuse can lead to teenage pregnancy. Most of them (88.9\%) signified that, especially the act of sexual abuse may resultantly lead to teenage pregnancy more than any other forms of child abuse.

Overwhelming number of our respondents $(83.9 \%)$ were of the view that teenage pregnancy usually affects on Nigerian Society (71.7\% testified to this).

From the hypotheses we tested in this study, we discovered that poverty may induce child abuse which may consequently lead to teenage pregnancy. Poverty is the most critical household problem in Nigerian Society today. Poverty has destroyed the good structure of many Nigerian families and exposes them to myriad of problems. Furthermore, our second hypothesis also testified that child neglect may invariably cause teenage pregnancy too. Many parents do neglect the care and provision that they are supposed to render to their children. This may be as a result of many socio-economic problems in the nation and some cultural belief system. Neglect may force the female children into the hands of the social predators. These girls satisfy their basic needs in exchange for abusive sexual intercourses. Many of these abusive sexual intercourses had led to teenage pregnancies which had ruined the lives of many teenage girls and consequently affected the society.

Finally, we find out that abuse of child ren in all forms may, one way or the other, expose the female teenagers to teenage pregnancy. The most critical of these abuses is sexual abuse. Other abuses like physical abuse, emotional/psychosocial abuse, verbal abuse and child labour do one way or the other expose teenage girls into some danger which may result in teenage pregnancy.

\subsection{Conclusions}

We discover from our research study that a significant relationship exists between poverty and teenage pregnancy. Poverty may push female children into illicit sexual act that may result into teenage pregnancy.

We also discover that child neglect also has significant relationship with teenage pregnancy. Neglect by parents may expose female children to sexual abuse which may eventually lead to teenage pregnancy.

Child abuse was also discovered to have a correlation with teenage pregnancy. Many teenage mothers had unwanted sexual experiences (abuse) prior to their pregnancies.
Child abuse should be taken seriously in our society. Abuse of children will always create problems for those children and the society at large. Abuse may cause the children to be depressed. It may make them lose their self esteem, self confidence and ego. Abuse may affect the academic performance of the children involved, and thus make them distrust others and cause sleeping disorder and self destructive behaviours. Abuse may cause teenage pregnancy which has many consequences itself i.e. premature babies, comp lications during birth, stig matization and economic burden. The correlation which exists between child abuse and teenage pregnancy is a clear indication that if the problem of child abuse in all forms is genuinely attended to in the Nigerian society, it will reduce the rate of teenage pregnancy among the female teenagers in Nigeria. This is especially in the case of the sexual abuse; but the other forms, too, should be well taken care of.

\subsection{Recommendation}

We deem it fit to proffer some recommendations to address the issue of child abuse and teenage pregnancy, within the context of Nigerian Society, in order to arrest the ugly situation.

Parents should be sensitized on the problem of child abuse. Some parents cannot distinguish between child abuse and discipline at homes. Public awareness on what constituted abuse of child must be increased throughout the nook and cranny of the Nigerian Society. Parents need to understand what child abuse really is and the forms of the abuse. So me consider abuse as discipline but they are two different things .The parents must be schooled on what constitute abuse and what discipline is all about, as well as the point where the two intersect or where discipline crosses over and becomes an abuse. Moreover, some parents lack good act of parenting. Some Nigerian parents need to be taught the act of parenting. We therefore, recommend public talks, seminars, workshops, training e.t.c by the government, non-governmental organizations and religious bodies to assist in this regard.

The government must also take the issue of child abuse seriously. The laws that protect the rights of the children must be fully implemented with all sincerity. The vio lators of the law must be judiciously prosecuted by the law enforcement agencies. We recommend the training of some officers of law that would specially take care of the investigation and prosecution of child abuse cases in the country. Such will deter the incidences of child abuse in the country. We equally want the government to always review laws protecting the rights of children in line with the updated law at the international level. Such laws must also be implemented.

We equally implore the non-governmental organizations and relig ious bodies to assist in launching and implementing programs of various forms that would counter the problems of child abuse in the country.

In the area of teenage pregnancy, we want the government to always prosecute the men who impregnate teenagers. The 
men must be prosecuted and be made responsible for the care of the victims. This must involve the health care and the provision of basic necessity for the teenagers and their children. Furthermore, we solic it that government create a social welfare department that will assist the teenage pregnant girls. Government should assist them by making relief provision available to them. Social workers and councilors must be employed that would assist them and counsel them.

We believe that doing this will remove the emotional stress, psychological problem and health challenges they may have. We want the govern ment to give free medical care to them and their children and to support them economically in order that they may be able to cater for themselves and their children.

We want periodic counseling for them especially in the art of parenting which must involve how to take care of their babies and grow those babies up in a good parenthood. We believe that doing this will give them the opportunity to overcome the challenges they may encounter as a result of their teenage pregnancies prompted by child abuse in our society.

\section{REFERENCES}

[1] Adler, Emily, Stier and Clark, Roger How it is done: An Invitation to Social Research, Wadworth Publishing Company, Canada,1999.

[2] Briere, John Child Abuse Trauma: Theory and Treatment of the Lasting Effects (Interpersonal Violence: The Practice Series) Sage Publications, Newbury Park, London, 1992.

[3] Brook - Gnn, J. and Furstenberg, F.F. 'Adolescent Sexual Behaviour’ American Psychologist, vol.44,pp. 149-259,1989.

[4] Carballo, M.'Parents Mistreatment' World Health Organization, Geneva, 1995.

[5] Child Help USA 'Child Abuse Prevention: National Child Abuse Hotline'. Online Available: http//www.childabuse. com, 2012.

[6] Cichetti, D. and Toth, S.L 'A Developmental Psychology of Perspective on Child Abuse and Neglected Children', Developmental Psychology, vol.29, pp.53-62, 2008.

[7] Cook, O.L and Bowells, J. Child Abuse: Commission and Admission, Butters Work, Toronto, 1980.

[8] David, G Violence against Children, Harvard University Press, USA, 1979.

[9] Drybury, H 'Teenage Pregnancy', Health Repots,vol.12 no.1,pp. 9-18,2002.

[10] Dryfoos, Joy. G. Adolescent at Risk: Prevalence and Prevention, Oxford University Press, New York, 1990.

[11] Ebigbo, P.O. 'Situation Analy sis of Child Abuse and Neglect in Nigeria: Making use of Nigeria Daily Newspaper', Journal of African Psychology vol.2, pp. 95-101, 1989.
[12] Ebigbo, P.O. and Abaga, S. 'Sexual Experience of Street Trading Girls in City of Enugu 'in proceedings of 1990 ISPCAN Eight International Congress on Child Abuse and Neglect, Hamburg, Germany,1990.

[13] Edu, D.O. and Edu, G.O. 'Child Abuse in Nigeria: Its Impact on Child Development' in proceeding at the First Zonal Conference of the National Association of Women Academics, University of Uyo, Awka Ibom State, Nigeria, 1999.

[14] Emery, R.E 'Family violence', American Psychologists vol. 44, pp. 3231-328,1989.

[15] Finkhelor, David'Report on the International Society for Child Abuse and Neglect (ISPCAN)'.Online Available : http://ispcan.org,2001.

[16] Furstenberg, F.F., Brooks-Gunn J. and Chaselansdale, L. American Psychologist vol. 44, pp.313-320,1989.

[17] Gelles, R.J 'Child Abuse as Psychopathology: A Social Critique and Reformulation', American Journal of Orthop sy chiatry, vol. 43,pp. 611-621,2001.

[18] Givannoni, J.M. Definitional Issues on Child Maltreatment: Theory and Research on the Causes and Consequences of Child Abuse and Neglect, Cambridge University Press, . Cambridge, 2000.

[19] Hamnasu, Takele 'Impact of Childhood Abuse on Adult Health', Amberton University, 2000.

[20] Heyman, S. and Slep J.I 'Child Abuse'. Microsoft Encarta. Online Available: http://microsoftcorporation.org,2002.

[21] International Labour Organization 'Global Report on Child Labour’. Online Available: http//Ilo.org,1978.

[22] Kempe, H 'Introduction to Battered Child Syndrome'. Online Available: http//Kempe .org, 1962.

[23] Kimberly, S 'Article on Maltreated Children'. Online Available: http//:unesco.org,2001.

[24] Locoh, T 'Early Marriage and Motherless in Sub-Saharan Africa.' Online Available :http:// Ajol.info,2000.

[25] Neuman, W. Lawrence Social Research Methods: Qualitative and Quantitative, A and B, USA, 2003.

[26] National Research Centre for Women and Families 'Teen Pregnancy: Rate Reaches a Record Low in 1997'.Online Available: http//:Cdc.go/nchs/,2001.

[27] Olukoshi, A.O. The Child in the Contemporary Nigeria: An Introduction to Issues, Lamirex Printing Press,Lagos, 1990.

[28] Otensaya, B 'The Psycho- Social Dimension of Sexually Transmitted Disease: A Case study of Ahmadu Bello University Teaching Hospital', MSc Thesis, Department of Sociology, Ahmadu Bello University, Zaria, Nigeria, 1987.

[29] Patience, J 'Childhood Sexual Abuse', Child Abuse and Neglect, pp.11-12, 1996.

[30] Portwood, S 'The Impact of Individuals Characteristics and Experiences on the Definitions of Child Maltreatment' Child Abuse and Neglect, vol.22, pp.437-452, 1998.

[31] Rebecca, W Child Abuse: Implication for Child Development, Sage Publication, Oaks, 2004. 
[32] Roister, O and Mckenzie, S. 'Article on the Physically Abused Children': Online Available: http//:rainn.org,1994.

[33] Ross, S.M 'Risk of Physical Abuse to Children of Spouse Abusing Parent' Child Abuse and Neglect, vol.20 no.7,pp. 587-598, 1998.

[34] Straus, M.A. and Gelles, R.J. Societal Change and Change in Family Violence from 1975-1985 As Revealed By Two National Surveys in Straus, M.A. and Gelles R.J. (Eds) Physical Violence in American Families, Transactional Publisher, New Brunswick, N.J,1990.
[35] Schutt, Russell K. Investigating the Social World - The Process and Practice of Research 4th edition, Pine Forge Press, USA,2004.

[36] Treffers, P.E.C 'Teenage Pregnancy: A World Wide Problem'. Online Available :http//:ncbi.nlm.nih.gov,2003.

[37] UNICEF 'A League Table of Teenage Births in Rich Nations. Innocent Report Card No3 'Online Available :http//: unicef.org, 2004.

[38] Villigrosia, M 'Sexual Abuse among Female Children'. Online Available :http//:.Act hhs.gov,2002. 